\title{
ANALISIS TINGKAT PENDAPATAN, PENGGUNAAN ALAT TANGKAP IKAN DAN TEKNOLOGI INFORMASI PENGARUHNYA TERHADAP PERUBAHAN SOSIAL KEMASYARAKATAN NELAYAN STUDI KASUS: DESA MUNJUNGAGUNG KABUPATEN TEGAL
}

\author{
Hajar Adhayanti ${ }^{1}$, Ahmad Maulana ${ }^{2}$ \\ email: miz_hajar@yahoo.co.id \\ ${ }^{1,2}$ Politeknik Harapan Bersama, Jalan Mataram No.9 Kota Tegal 52142, Indonesia Telp (0283) 352000
}

\begin{abstract}
Abstrak
Munjung Agung atau Larangan merupakan salah satu desa yang berada di kecamatan Kramat, Kabupaten Tegal, Provinsi Jawa Tengah, Indonesia. Berada di pesisir laut jawa dan salah satu desa nelayan yang ada di Kabupaten Tegal. Masyarakat desa nelayan merupakan masyarakat marjinal yang menempati daerah kumuh di pinggiran kota yang berbatasan dengan laut. Namun dengan adanya perubahan penghasilan yang diterima oleh nelayan Munjung Agung terjadi perubahan sosial kemasyarakatan. Pada penelitian ini menggunakan tiga variabel dependen diantaranya tingkat pendapatan, penggunaan alat tangkap ikan dan teknologi informasi. Alat analisis mengunakan penelitian kuantitatif, dengan Data diolah menggunakan aplikasi SPSS dengan melakukan pengujian uji validitas, uji reabilitas, uji normalitas, uji homogenitas, uji regresi linier sederhana dan uji regresi linier berganda, data diperoleh dengan cara penyebaran kuesioner menjawab pernyataan yang diajukan oleh penulis kepada nelayan Desa Munjung Agung untuk mengetahui tingkat pendapatan, penggunaan alat pancing dan teknologi informasi berpengaruh terhadap perubahan sosial kemasyarakatan. Hasil penelitian menunjukkan bahwa tingkat pendapatan, penggunaan alat tangkap ikan dan teknologi informasi berpengaruh signifikan terhadap perubahan sosial kemasyakatan nelayan Desa Munjung Agung Kabupaten Tegal.
\end{abstract}

Kata kunci:Tingkat pendapatan, penggunaan alat tangkap ikan, teknologi informasi, dan masyarakat nelayan

\section{Pendahuluan}

Desa Munjung Agung merupakan salah satu desa yang berada di kecamatan Kramat, Kabupaten Tegal, Provinsi Jawa Tengah, Indonesia. Berada di pesisir laut jawa dan berbatasan dengan desaKramat (timur), Bongkok (selatan), dan Padaharja (barat). Munjung Agung adalah salah satu desa nelayan di pesisir Kabupaten Tegal.Berdasarkan data penduduk menurut mata pencaharian sebagai nelayan sebanyak 1.124 jiwa. Masyarakat desa nelayan merupakan masyarakat marjinal yang menempati daerah kumuh di pinggiran kota yang berbatasan dengan laut. Desa nelayan sebagai pemukiman itu sendiri tercermin dari kondisi lingkungan perumahan yang relatif buruk sehingga kurang memenuhi standar kesehatan. Fasilitas air bersih tidak dimiliki oleh semua warga, melainkan milik bersama atau umum. Fasilitas kesehatan juga sulit diperoleh. Keadaan seperti ini pernah dialami oleh masyarakat nelayan Desa Munjung Agung Kabupaten Tegal.

Terdapat perubahan sosial pada masyarakat nelayan di Desa Munjung Agung. Dari segi pendapatan nelayan sudah tergolong ekonomi menengah, ini ditandai dengan daya beli mereka yang meningkat. Contohnya, rumah yang mereka huni tergolong rumah sehat serta adanya kendaraan yang mereka miliki. Memberikan pendidikan yang layak bagi anak - anak mereka.Tujuan penelitian ini adalah untuk mengetahui tentang Analisis Tingkat Pendapatan, Penggunaan Alat Tangkap Ikan Dan Teknologi Informasi Terhadap Perubahan Sosial Kemasyarakatan Nelayan Studi Kasus Desa Munjung Agung Kabupaten Tegal.

\section{Metode Penelitian}

Peneliti menggunakan metode kuantitatif, observasi secara deskriptif yaitu 
peneliti berusaha untuk mengamati merekam mencatat dan mendokumentasikan keadaan masyarakat nelayan yang ada di Desa Munjung Agung di Kabupaten Tegal. Pengumpulan data juga dilakukan dengan lembar pertanyaan terstruktur yaitu teknik pengumpulan data dengan memberikan atau menyebarkan daftar pertanyaan kepada responden dengan harapan memberikan respon jawaban dari bagaiman perubahan sosial yang terjadi pada nelayan di Desa Munjung Agung Kabupaten Tegal.

Penelitian dilakukan dengan membagikan kuesioner dan wawancara mendalam yang kemudian data dilakukan analisis menggunakan analisis deskriptif.

\section{Hasil dan Pembahasan}

Penelitian dilakukan pada 92 responden yang berprofesi sebagai nelayan. Deskripsi responden berdasarkan jenis kelamin selurunya berjenis kelamin lakilaki. Dan deskripsi responden berdasarkan agama seluruhnya beragama Islam.

Berdasarkan tingkat penghasilan, responden terbanyak berpenghasilan per bulan rata-rata $\mathrm{Rp} 1.500 .00,-\mathrm{s} / \mathrm{d} \mathrm{Rp}$ 2.500.000,- sebanyak 40\%. Berdasarkan usia responden terbanyak usia $37 \mathrm{~s} / \mathrm{d} 48$ tahun yaitu sebanyak 55\%. Data responden berdasarkan status perkawinan yaitu yang menikah sebanyak $60 \%$.

a. Kontribusi Variabel Tingkat

Pendapatan

Variabel tingkat pendapatan memberikan kontribusi signifikan terhadap perubahan sosial kemasyarakatan dengan signifikansi sebesar 0,000.Hipotesis ini terbukti bahwa variabel tingkat pendapatan berpengaruh signifikan terhadap perubahan sosial kemasyaraktan nelayan Desa Munjung Agung.Hal ini memberikan gambaran kondisi nelayan yang ada di Desa Munjung Agung bahwa tingkat pendapatan terjadi perubahan sosial kemasyarakatan.Indikator diantaranya modal kerja hasil analisis data deksriptif sebanyak $75 \%$ responden menyatakan setuju, hal ini relevan dengan hasil wawancara penulis dengan responden bahwa modal kerja untuk melaut mempengaruhi hasil tangkapan ikan. Kemudian indikator jumlah anak buah kapal
(ABK) hasil analisis data deskriptif sebanyak43,5\% responden menyatakan setuju bahwa jumlah ABK yang disesuaikan dengan kapasitas kapal. Kapal yang besar membutuhkan banyak anak buah kapal. Indikator waktu selama berada di laut hail analisis data deskripftif sebanyak 58,7\% responden menyatakan setuju bahwa penangkapan ikan lepas pantai dilakukan waktu yang lebih lama dan memperoleh hasil tangkapan yang lebih banyak.

Indikator kebutuhan primer hasil analisis data deskriptif sebanyak 50\% responden menyatakan sangat setuju bahwa terpenuhinya kebutuhan primeroleh nelayan Desa Munjung Agung. Indikator pendidikan hasil analisis data deskriptif sebanyak $41,3 \%$ responden menyatakan tidak setuju bahwa anak-anak mereka diberikan pendidikan yang lebih baik, hal ini relevan dengan hasil wawancara penulis kepada responden bahwa masih banyak anak-anak nelayan Desa Munjung Agung sekolah hanya sampai pada tingkat SD, hal ini dikarenakan anggapan bahwa pendidikan tidak terlalu penting dan anak-anak yang tidak melanjutkan ke tingkat berikutnya mereka sudah diajarkan untuk bekerja sebagai anak buah kapal (ABK).

Makin tinggi modal kerja per unit usaha yang digunakan maka produksiikan lebih baik. Banyaknya tenaga kerja disesuaikan dengan kapasitas kapal motor yang dioperasikan sehingga menguruangi biaya melaut. Curahan tenaga kerja yang dipakai adalah besarnya tenaga kerja efektif yang dipakai. Penangkapan ikan lepas pantai yang dilakukan dalam waktu yang lebih lama dan lebih jauh dari daerah sasaran tangkapan ikan memperoleh hasil tangkapan (produksi) yang lebih banyak dan memberikan pendapatan lebih besar. Kebutuhan primer tidak lagi menjadi hal yang sulit oleh nelayan karena tingkat pendapatan yang diperoleh mereka.

b. Kontribusi Variabel Penggunaan Alat

Pancing

Variabel penggunaan alat pancing memberikan kontribusi signifikan terhadap perubahan sosial kemasyarakatan dengan signifikansi sebesar 0,003.Hipotesis ini terbukti bahwa variabel penggunaan alat pancing berpengaruh signifikan terhadap 
perubahan sosial kemasyaraktan nelayan Desa Munjung Agung.Indikator dalam variabel ini adalah penggunaan alat pancing yang digunakan nelayan selama melaut tidak mengalami hambatan pada hasil analisis data deskriptif sebanyak 59,8\% responden menyatakan setuju.Hal ini relevan dengan hasil wawancara penulis dengan responden bahwa kondisi nelayan yang ada di Desa Munjung Agung bahwa alat pancing yang digunakan untuk menangkap ikan di laut tidak mengalamai hambatan.

Indikator lain yaitu penggunaan alat pancing didukung oleh alat mesin kapal/perahu yang memadai pada hasil analisis deskriptif sebanyak 54,3\% responden menyatakan cukup setuju. Kemudian penggunaan alat pancing ikan cantrang meningkatkan hasil tangkapan ikan pada hasil analisis data deskriptif sebanyak 48,9\% responden menyatakan setuju meskipunterdapat Permen Kelautan dan Perikanan No 2/2015 tentang Pelarangan Penggunaan Alat Penangkapan Ikan Trawl danSeine Nets, nelayan berharap ada solusi dari Pemerintah untuk mengatasi hal tersebut.

$\begin{array}{llll}\text { c. } & \begin{array}{l}\text { Kontribusi } \\ \text { Informasi }\end{array} & \text { Variabel } & \text { Teknologi } \\ \text { Variabel } & \text { teknologi } & \text { informasi }\end{array}$
memberikan kontribusi signifikan terhadap perubahan sosial kemasyarakatan dengan signifikansi sebesar 0,003.Hipotesis ini terbukti bahwa variabel teknologi informasi berpengaruh signifikan terhadap perubahan sosial kemasyaraktan nelayan Desa Munjung Agung.Hal ini memberikan gambaran kondisi nelayan yang ada di Desa Munjung Agung bahwa adanya kemajuan teknologi informasi telah terjadi perubahan sosial kemasyarakatan.

Indikator handphone / smartphone hasil analisis data deskriptif sebanyak 41,3\% responden menyatakan tidak setuju bahwa menggunakan handphone berbasis smartphone untuk berkomunikasi. Hal ini relevan dengan hasil wawancara penulis kepada responden, untuk berkomunikasi handphoneyang digunakan tidak harus berbentuk smartphone, karena mereka menggunakan handphone hanya untuk menelepon keluarga saja pada saat mereka mendarat selama dalam masa bekerja atau melaut. Indikator media audio visual hasil analisis data deskriptif sebanyak 33,7\% responden menyatakan setuju bahwa nelayan Desa Munjung Agung menggunakan media audio visual seperti televisi di dalam rumah. Hal ini relevan dengan hasil wawancara karena televisi merupakan media yang paling mudah untuk mendapatkan informasi melalui acara dan sebagai hiburan yang dapat dinikmati oleh anggota keluarga. Indikator media sosial hasil analisis data deskriptif sebanyak $39,1 \%$ responden menyatakan setuju bahwa menggunakan media sosial untuk mendapatkan informasi. Hal ini relevan dengan hasil wawancara penulis kepada responden bahwa media sosial saat ini sudah masuk ke lingkungan nelayan Desa Munjung Agung. Pengguna media sosial di lingkungan nelayan tersebut tidak hanya oleh nelayan sebagai kepala keluarga namun juga oleh istri dan anak-anak mereka. Indikator internet hasil analisis data deskriptif sebanyak $58,7 \%$ responden menyatakan sangat setuju bahwa menggunakan internet sebagai sarana untuk mencari informasi dan sosialisasi. Hal ini relevan dengan hasil wawancara kepada responden bahwa mereka mengakses informasi secara cepat dan praktis dan juga sebagai alat bersosialisasi.

d. Kontribusi Variabel Perubahan Sosial Kemasyarakatan

Variabel perubahan sosial kemasyarakatan secara signifikan mempengaruhi secara langsung atau tidak langsung kepada variabel tingkat pendapatan, penggunaan alat pancing, teknologi informasi. Perubahan sosial kemasyarakatan dengan signifikansi sebesar 0,000.Hipotesis ini terbukti bahwa faktor perubahan sosial kemasyarakatan nelayan Desa Munjung Agung mempengaruhi secara signifikan tingkat pendapatan, penggunaan alat pancing dan teknologi informasi.

Berikut ini adalah keterangan frekuensi dari masing-masing indikator variabel kepuasan pengunjung:

Pemenuhan kebutuhan fisiologis yaitu pemenuhan kebutuhan pangan, pakaian dan tempat tinggal nelayan hasil data analisis deskriptif sebanyak $56,5 \%$ responden 
menyatakan setuju. Hal ini relevan dengan wawancara kepada responden ada beberapa pernyataandengan penghasilan mereka dapatkan kebutuhan fisiologis terpenuhi. Indikator kesejahteraan hasil data analisis deskriptif sebanyak $54,3 \%$ responden menyatakan sangat setuju bahwa peningkatan kesejahteraan melalui pendapatan yang meningkat sebagai nelayan Desa Munjung Agung. Indikator penghargaan berupastatus sosial hasil data analisis deskriptif sebanyak $41,3 \%$ responden menyatakan tidak setuju bahwa status sosial yang ada di masyarakat terhadap nelayan berubah. Indikator aktualisasi diri hasil data analisis deskriptif sebanyak $33,7 \%$ responden menyatakan cukup setuju bahwa keutuhan untuk memenuhi keberadaan diri dengan memaksimumkan penggunaan kemampuan dan potensi diri.

\section{Kesimpulan}

Berdasarkan hasil penelitian dan pengujian hipotesis yang dilakukan, menunjukkan tingkat pendapatan yang diperoleh nelayan Desa Munjung Agung mengakibatkan perubahan sosial kemasyarakatan. Penggunaan alat pancing oleh nelayan Desa Munjung Agung mengakibatkan perubahan sosial kemasyarakatan. Teknologi informasi mengakibatkan perubahan sosial kemasyarakatan nelayan Desa Munjung Agung.Variabel perubahan sosial kemasyarakatan mempengaruhi secara langsung maupun tidak langsung kepada variabel tingkat pendapatan, penggunaan alat pancing dan teknologi informasi. Indikator variabel perbahan sosial kemasyarakatan yaitu kebutuhan dasar, kesejahteraan, status sosial, aktualisasi diri. Terpenuhinya kebutuhan dasar, kesejahteraan, status sosial, aktualisasi diri mengakibatkan perubahan sosial kemasyarakatan.

\section{Daftar Pustaka}

[1] Fahrozy, A, "Model Peningkatan Pendapatan Ekonomi Masyarakat Kawasan Taman Nasional Tanjung Putting Dalam Pengembangan Destinasi Tujuan Wisata Kabupaten Kota Waringin Barat, Kalimantan Tengah", Proposal Thesis, 2015, tidak dipublikasikan.

[2] Haba, John "Realitas Masyarakat Adat di Indonesia : Sebuah Refleksi, Jurnal Masyarakat Dan Budaya", Pusat Penelitian Kemasyarakatan dan Kebudayaan LIPI, 2010

[3] Idrus, Muhammad, Metode Penelitian Ilmu Sosial, Erlangga, Jakarta, 2009.

[4] Laporan Monografi Dinamis Tahun 2016 Desa Munjung Agung Kecamatan Kramat, Kabupaten Tegal

[5] Moleong Lexy J, Metodologi Penelitian Kualitatif, PT. Remaja Rosdakarya, Bandung, 2010.

[6] Manan, M. Azzam, "Nelayan Desa Bendar: Strategi dalam Mengatasi Kendala Usaha Perikanan Tangkap", Pusat Penelitian Kemasyarakatan dan Kebudayaan LIPI, 2010.

[7] Romdiati, Haning dkk, Kondisi SosialEkonomi Masyarakat di Lokasi COREMAP II: Kasus Kabupaten Biak Numfor, LIPI Press, Jakarta, 2008.

[8] Soekanto, Soerjono, Sosiologi Suatu Pengantar, PT. RajaGrafindo, Jakarta, 2003.

[9] Sugiyono (2015), Metode Penelitian Pendidikan (Pendekatan Kualitatif, Kuantitatif, dan R\&D), CV. Alfabeta, Bandung

[10] Shadili, Hasan, Sosiologi Untuk Masyarakat Indonesia, PT. Rineka Cipta, Jakarta, 1993

[11] Usman, Sanyoto, Perubahan Sosial, Pustaka Pelajar, Jogjakarta, 2015

[12] Zamroni, Imam, "Perubahan SosialBudaya Petani Organik di Yogyakarta", Jurnal Masyarakat dan Budaya Vol. 12 No. 1, PMB-LIPI, Jakarta, 2010. 